\title{
Disgust and Distinction: The Case of the Jellied Eel
}

\section{Abstract}

Drawing an a series of ethnographic encounters collected while hanging around at a seafood stand in east London, the following article aims to explore the relationship between individual expressions of distaste and the production of class, ethnic and generational forms of distinction. Starting with the visceral expressions of distaste directed towards a seafood stand, the following paragraphs draw on a combination of historical and ethnographic data rendered through a matrix of anthropological, sociological and psychoanalytic theory, to explore the role of everyday ambient experiences and the stratifying processes that that cut across the lives of the city's inhabitants. Arguing against purely biological explanations of disgust, the paper explores how social histories and cultural experience inflect gut responses to the sensoria that suffuse urban environments. Moving the focus beyond the social construction of urban sensibilities, the paper goes on to develop an account of culturally inflected forms of distaste, shaping the city and the lives of its inhabitants.

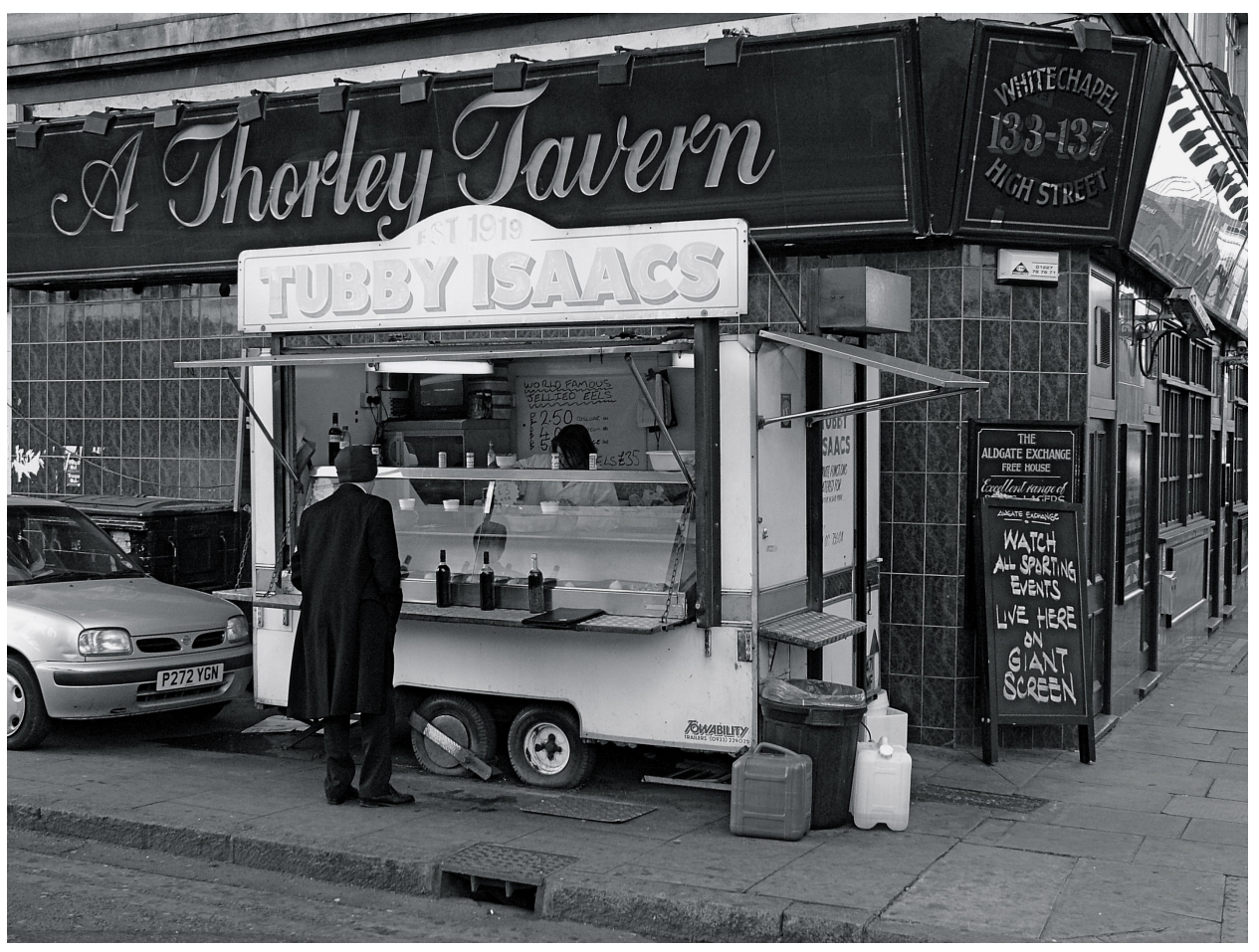

Figure 1. Tubby Isaac's, 2008, author's own photo 


\section{Introduction}

The following paper aims to explore the relationship between everyday expressions of disgust, and the processes of social distinction that shape everyday life in a post-industrial urban context. Pitching a heterodoxy of psychoanalytic, anthropological and sociological theories of disgust, abjection and distaste (Kristeva 1982, Douglas 2002, Bourdieu 1984) against prevailing biological accounts of disgust, the intention is to reveal the complex cultural construction of local forms of distaste. In particular, honing an ethnographic attention on a particular urban location and it's concomitant sensoria, the paper explores the regimes of distaste informing British class cultures, and their actualisation in cities. Adding an important consideration of distaste to a rich literature on the interaction between taste and class (Charles and Kerr 1988, Lawler 2005, Lupton 1996, Bourdieu 1984, Bennet et al. 2009) the intention is to use ethnographic data expand the analysis into a consideration of the tangle of generational distinctions that both interfere and resonate with class culture through distaste.

Taking a handful of scenes from a single ethnographic site, the paper develops an account of urban experiences fortifying a tangled braid of social classifications. Operating within a 'democracy of the senses' (Berendt 1992, 32) the paper is part of a wider attempt to explore the relationship between the ambient sensoria that suffuse urban space, and the articulation of class culture and ethnicity within contemporary cities. Given the necessary lack of conscious reflection on ambience and the difficulty interviewing potential research participants directly about their sensory experiences, the immersive nature of an ethnography gives it a special utility in developing an understanding of the relationship between low level bodily experiences, and social processes. The specific site this paper focusses on is a small white sea food trailer in east London (see Figure 1), sandwiched between the opulent jewels of London's financial district, the heritage lead regeneration of Spitalfields and the obdurate poverty of Whitechapel. It was visited by your author - in the capacity of an observing 
customer - up to four times a week for a three year period, during which time experiences were garnered, conversations struck up and insights gained that gradually revealed people's relationships with the ambience of that space and others. All names have been removed or changed except for the name of the trailer, Tubby Isaac's, and it's proprietor, Paul. Customers that were spoken to regularly, and those that were portrayed in photographs were made aware of what the stranger with a notepad and camera was doing hanging around the site. Those passing by were informed when possible, but not always. We will start at the site as it was found on a cold and damp morning early in April 2008.

A black taxi cab with a small St George's flag in the back window turns into Goulston Street, east London. He drives slowly, passing the skeletons of market stalls and the rusted shutters clamped over shopfront windows towards a small food trailer at the southern end of the street. The driver parks his car carefully in a spot opposite Tubby Isaac's sea food stand. Kicking the door open, he eases himself out. He is of medium build, about five feet and eight inches tall, white, and the fasten ers on his jacket strain under the task of holding back his gut. He wears small metal-rimmed glasses of medium thickness and is about forty-five years old, although having been sitting in his cab for hours looks considerably older as he makes a short hunched walk from the car over to the stand. Besides myself and passers-by that stopped to ask for directions to the boutiques of Spitalfields, the seafood stand has been empty for about twenty minutes. The driver shuffles towards the stand, spine still curved. Upon reaching it, he places two thick hands on the steel counter in front of him, and in one deep inhalation, rolls back his shoulders and lifts his chin towards the vendor, who stands about half a metre above his eye line.

'All right there Tubby. Still killin' them Chinese?'1

The vendor (Paul, not Tubby), faintly smiles a smile to suppress a cringe - an attempt to create dis tance from a distasteful joke that, if overheard, stands to cast both the teller and receiver in bad 
light. In this case the joke is at the expense of twenty-one Chinese migrants who drowned farming Lancashire's rich cockle beds.

Paul nods a 'Hello,' with his eyebrows raised, before adding 'You know that those Chinese were farming exports to Spain?'

I nod and scribble.

The customer seems not to have listened, or chooses to pretend he has not. He glances over the vendor's shoulder at the fuzzy news footage playing on the small portable television that sits at the back of the stand. The footage is of the first of many Olympic torch precessions moving through east London.

'I'll 'ave a medium bowl of eels to eat here, and a dressed crab to take home please.'

Paul warms to the customer a little more.

'Hundred pound, minimum spend today.'

This time a more substantial chuckle is shared.

Having been handed the eels in a small porcelain bowl over the high counter, the customer places it on the steel shelf at his waist and pours chilli vinegar over the eels until the bowl overflows. He picks the bowl back up, and hunching over it with a small plastic fork, starts shoveling the eel pieces into his mouth, at first spilling jelly and dark brown vinegar from the over full bowl on to the pavement beneath him. Pigeons scut about his feet waiting for every morsel that misses his mouth. For the next five minutes the only noises he makes are satisfied grunts and snuffles, breaking only to straighten his back and glance over the vendor's shoulder to the crackling footage on the TV screen each time he needs to spit out an eel bone, before re-hunching over the bowl.

A couple, male and female, walk past the stall, and pause briefly behind the cab driver guzzling his eels.

The male half of the couple points enthusiastically at the display of molluscs and herring and says something inaudible. The woman curls her lip and tugs at her partner's elbow. They walk away. 
Having sucked all the flesh from the eel, and spat out the bones into a cardboard box beside the stand, the cab driver murmurs, 'Thanks Tubby, see you next time,' before glancing back up at the television and remarking: 'They'll get a shock when the torch comes east down here... They'll all be crowding round it for some heat, or to light their reefer.'

A laugh erupts between the vendor and his customer... I try not to laugh, to remain removed from the exchange, but my shuddering shoulders give me away.

At this last laugh, the customer picks up the blue polytene bag in which the dressed crab is wrapped, turns, and walks back to his cab, his arm aloft in the air. 'See ya, Tubby' he says, over his shoulder.

'Yeah, see ya,' says Paul, eyebrows again raised. The customer eases himself back into the hermetic security of his cab and, engine on, turns a famously tight circle in the road and drives back off the way he came.

\section{Local culture and transnational flavours}

From a sociological point of view, there is a great deal of interest within the foreground of this ethnographic encounter. Not least, amidst the exchange between the vendor and his grunting customer, it is possible to see aspects of a relaitonship between the consumption of local flavours, and the construction of an exclusive local ethnicity. For this taxi driver, as with a number of other London-born men - particularly those embodying an ostensibly white, working-class culture - the flavours of the estuarial eels and cockles are important props in the story of an indigenous 'island race' to which they feel they belong (Cohen, 1998). The story about an indigenous island, increasingly inundated by alien cultures is, for some customers, ratified by presence beside the seafood stand of a falafel stand, two Thai food trailers, a 'Tikka Truck' and a Japanese takeaway stand, all with longer queues than Tubby Isaac's. Yet if we are to entertain the notion that regions are partly articulated through acts of gustation (Bell and Valentine, 1997: 150), then the first thing that we should note is that technically, the food sold at this stand is as global as it's neighbours. Its speciality eels are indicative in this sense: Born in the warm waters of Sargasso sea, the European eel (Anguilla anguilla) migrates 
north and eastward and, if they make it past Spanish elver nets, arrive in north European inland waters where they live until full maturity. It is when turning back to breed and die in Atlantic's warmer waters, that they are caught leaving the river estuaries of Scotland England, Ireland, France and Holland. As we will see later, the actual taste for these 'indigenous' morsels in London, like curry (Narayan, 1995) and fish and chips (Walton 2000) also has a cosmopolitan provenance typical of an erstwhile port city.

The foreground of this scene is certainly saturated with entry points into an understanding of the wider - often paradoxical - relationships between taste, geography and identity in a world city. However, of more interest to our current concerns, given the intended focus on distaste is what was going on in the background of the scene, with the young woman tugging her partner away from the seafood stand, her lip curling. Whether affected by the sight and smell of the glistening sea-fauna, offended by the humour expressed around the stand itself, or repelled by the appearance of the stand's patrons, the curling lip and scrunched up face is a remarkably common expression amongst the trickle of pedestrian traffic that drifts past the seafood stand each day. In fact, in contrast to many comparable northern European countries, across much of Britain, pickled herrings, oysters, mussels, crayfish, cockles, whelks and eels are met with such squirms. It was not, however, always the case, and for most part of the last millennium, a conspicuous taste for such food has been more common than distaste. At its peak in the late nineteenth century Henry Mayhew estimated that 932,340,000 tons of fish and other fruit of the sea and rivers were sold by London's street vendors to the city dwellers every year (Mayhew, 1851: 59). After a peak in the early twentieth century, the regular consumption of fish in Britain started decreasing, and has since declined rapidly (Chaloner in Barker et al. 1966: 94-115). It is undoubtable that a combination of overfishing alongside the loss of fishermen and boats to war in the last century diminished the consumption of meats from the estuaries and fringes of the British archipelago. Yet it is remarkable that today, even where the flavours of these salty shallows are readily available and exported en-masse to the rest of the world, their in- 
clusion within the culinary rhythms of city dwellers remains isolated to small groups. In contrast to previous centuries, distaste and disgust for these morsels is, however, far more commonplace (see Figure 2).

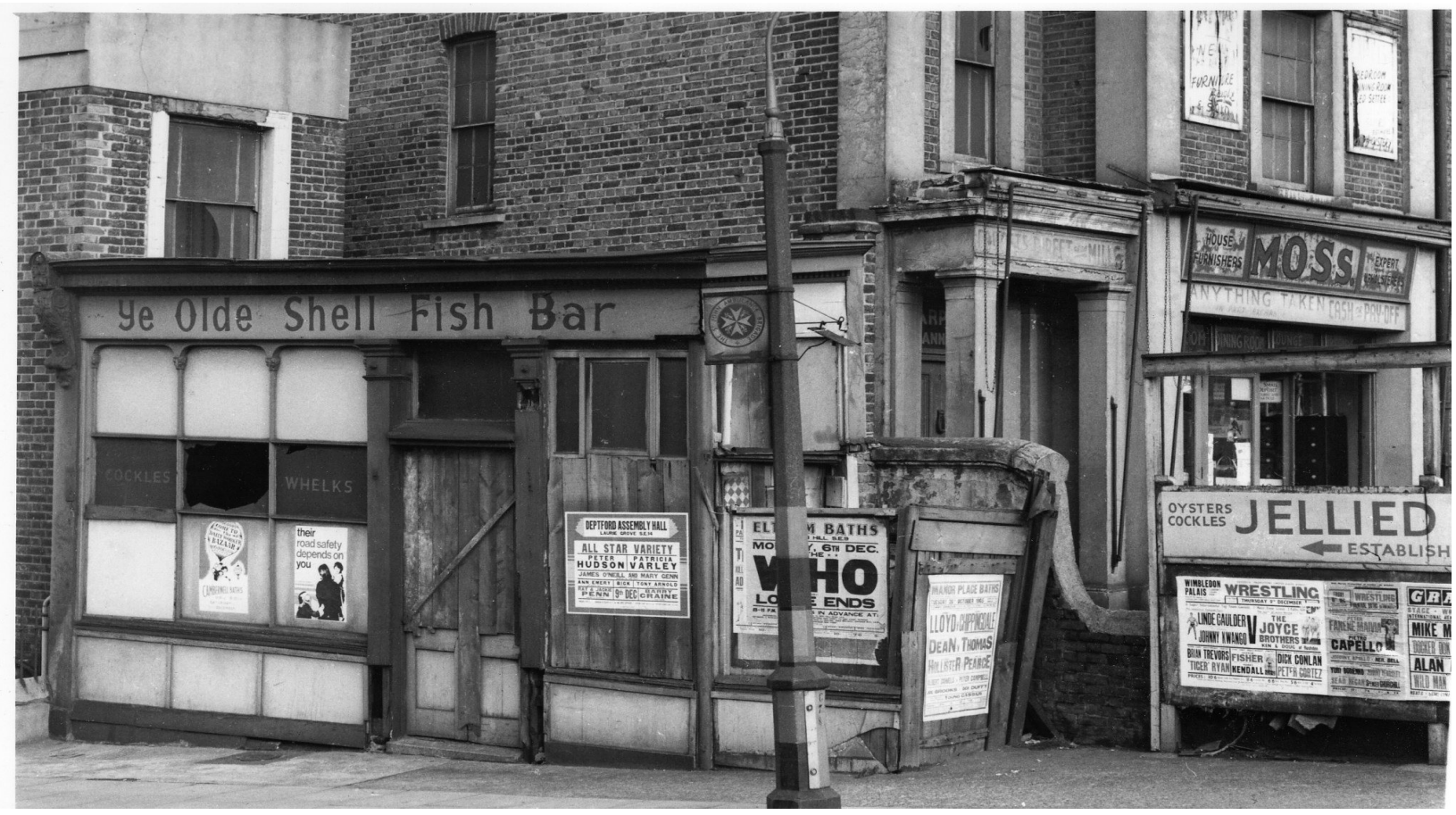

Figure 2. Ye Olde Fish Bar, Circa 1982, Lewisham Library Archive

\section{Epistemological Slipperiness}

Given the historical fluctuations in the taste and distaste for flavours of the Thames estuary - which would seemingly disqualifies any purely biological explanation for contemporary aversions to it - the maritime fauna sold at Tubby Isaac's provide the ideal starting point for understanding the complex relationship between modern social forms, the history of the city, and the regimes of taste and distaste that governs the city's inhabitants.

It is of course Mary Douglas's Purity and Danger that provides, what has been for nearly half a century, the leading anthropological account of disgust - or at least the dirt that precipitates it (Douglas, 2002). Importantly for Douglas, dirt was not an objective phenomenon, but rather a subjective or cultural construction. We'll return to Douglas's account of 'dirt' in a moment. For now, however, we will turn to the text she analyses in her theorisation of 'dirt,' The Old Testament; in which we find 
immediate explanation for the squirms directed at Tubby's piscine display cabinet. Nearly every species of the shimmering flesh on show in Tubby's glass cabinet - oysters, cockles, whelks, eels, prawns, scampi, squid and mussels - falls victim Mosaic prohibitions outlined in Leviticus:

'Anything in the seas or rivers that has not fins and scales, of the swarming creatures that are in the waters, is an abomination to you. They shall remain an abomination to you, of their flesh you shall not eat, and their carcass you shall have in abomination.' (Leviticus, 11:1)

Through the gustatory filters of Jewish, and Christian orthodoxy, everything excluding the herring and salmon sold at Tubby's, are an abomination. Such theological dietary prohibitions are certainly relevant to the social history of east London. From Benedictine fish Fridays of the Catholic city, through the kosher butchers and bakers of twentieth century, to the halal Haribo munched by the desi-cockneys of Brick Lane, theological proscriptions have shaped where people go, what they eat and who they eat it with. Such dictates are, however, unlikely to explain the preponderance of those who, when passing the seafood stand, appear disturbed by it. Moreover, it should also be noted that the original Tubby Isaac's, the portly cockney who first set up the eel stand in 1919, was a Jewish Russian migrant whose choice of food showed little regard for the dietary codes of his religion.

If it is not the theological dietary codes themselves that define the widely held aversion, then per haps it is their enduring, underlying logic. Certainly this was the view of what William James (1960, 28) refers to as, 'medical materialists' - those who maintain that all aspects of human behaviour are crude expression of biological imperatives. For Kellog (Douglas, 2002, 31) for instance, the origins of Mosaic prohibitions are to be found in what is referred to today as hygiene: a principle of rational cleanliness that transcends time yet which a particular group has an innate sensitivity to. While Kellog's explanation emerged from within the darkest recesses of nineteenth century biological determinism, his explanation is echoed in the contemporary era's favoured explanation as to how the body 
identifies and responds to dirt: that the identification of dirt and the response of disgust are objective biological 'response [that] guard[s] the internal milieu from pathogens and their toxic products, a homeostatic self defence system ... hard wired into our psyche' (Toronchuk, Ellis and George 2007: 1799, see also Angyal 1943, Öhman and Mineka 2001). Accordingly, the disgusting is understood within both the natural sciences, and the wider culture enamoured with the natural sciences certainty, as disgusting for a good reason, grounded in the limbic system's identification of a 'real,' biological threat. The same approach to dirt and disgust is operationalised by marine scientists and the governments fisheries department who have engaged in numerous attempts to answer why, 'in the U.K. the general public often still perceive seafood as 'risky' (Davidson and Bresnan, 2008). Believing that disgust is grounded in the objective calculation of biological risk, these researchers spend considerable resources conducting research into the phytoplankton blooms on which shellfish feed, looking for hidden toxins and threats that the public might sense.

It is, of course, entirely conceivable that the distaste increasingly expressed towards the fauna of the Britain's estuaries is attributable to a rationally calculated disgust. Doubtlessly seafood can leave the consumer incapacitated and, on occasion, dead. Bivalve molluscs (oyster, cockles and molluscs) in particular, because they live off effluent algae, are prone to the occasional accumulation of chemicals that are toxic to humans. While the shellfish trade is one of the most routinely and thoroughly inspected industries in Britain (owing to its importance as an export), a malevolent mussel must occasionally slip the net somewhere. However it is worth noting that no patrons of the stand has ever spoken of a bad experience, nor has your author ever experienced any illness as a result of consuming food from the trailer. If the squeamishness is rooted in the sensing of a perceived biological threat at the seafood stand, then that sensitivity is nonetheless, poorly calibrated and most likely exacerbated by a number of other factors. 
Given the frequent lack of correlation between these specific objects of disgust and genuine biological pathogens, it is not surprising that Douglas rejects the assertion that the 'abominable' is synonymous to the 'unhygienic,' and dismisses the possibility that Moses was an 'enlightened public health administrator' $(2002,37)$. She rejects these ideas not, however, on the basis that the 'primitives' were too irrational to understand hygiene. Rather on the basis that the biomedical notion of the 'unhygienic' often bares more resemblance to a 'primitive' or socially constructed notion of the abominable than biologists might admit. Put otherwise, for Douglas, there is no such objective thing as dirt 'except that which is [viewed through] a classificatory system in which it does not fit.' (2002, xvii). The Mosaic prohibitions for instance, Douglas argues, can be understood according to the ambiguity of the abominable items in view of the classical classificatory systems that prevailed at the time of writing. Through this anthropological account, which emphasises the plasticity of gut-feelings and the ability of vernacular knowledge inflect them, squirms don't merely emerge from within a hardwired homeostatic defence system of the body. Rather, they are a defence mechanisms of the wider culture and that lives through that body.

To be sure, there has to this dat been only a scattering of social scientific treatise on sea fauna (Cal lon 1986), seafood vendors (Back and Lyon 2012) and even fewer on contemporary perceptions of this redolent source of protein. However, it seems that when the policy makers at the Department for Environment, Food and Rural Affairs aim to establish why the British public see shellfish as 'risky,' (Davison and Bresnan, 2008) they might turn to social science and consider first, what deeply engrained symbolic orders seafood contravenes. If dirt and disgust is socially predicated in the way that Douglas' theory of dirt suggests, the answer to why people so regularly turn their noses up at Tubby Isaac's might lie in the following supplementary questions: What types of social order and cultural categories are reinforced through squirms directed at the stand? And the sociological question that follows it is: What might this tell us about the relationship between sensory experience, identity and social formation in cities today? 
First, it must be noted that on a general level, any flavour or smell has the potential to turn the stomach. Smells and tastes by their very nature, smudge a very important taxonomic division disturbing, by way of bodily orifices, a simultaneously psychic and physical sense of corporeal 'inside' and 'out' (Grosz 1994, 192-198). It is perhaps because smells and food necessarily disrupts this foundational boundary that Kristeva claims that 'food loathing is ... the most elementary form of abjection' $(1982,4)$. Yet we know that not all food induces gut-wrenching squirms. Rather, only the movement of certain tastes and textures into the mouth, or smells through the nose, result in the convulsion that ripples from stomach to lips and across the face. The distribution of these squirms, I will argue below, is partially predicated on the particular classificatory systems through which we sort our every day sensory experiences.

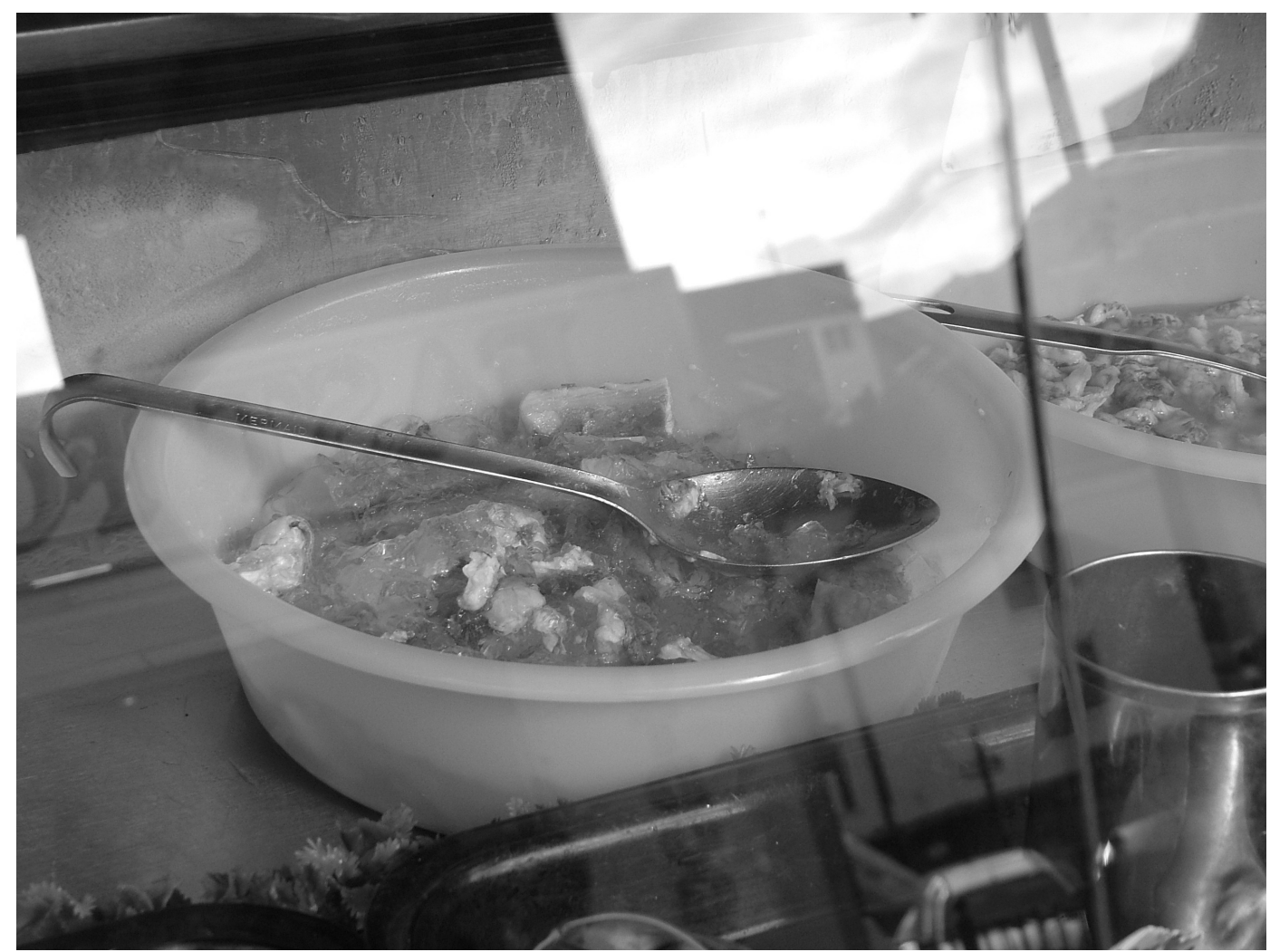

Figure 3. Jellied Eels, Tubby Isaac's, 2008, author's own photo

To approach an understanding of the classificatory systems disturbed by the seafood stand and its fare, it serves to turn first to what seems to be the most abject item sold there, consistently singled out by both passers, and even some regular customers, as an object of aversion. Amongst the various 
species of snack sold at the stand, it was doubtlessly the speciality eels and the jelly surrounding them that elicited more squirms than anything else (see Figure 3). So what classificatory systems then, does the jellied eel disturb? According to Linnaean taxonomy, the European Eel (Anguilla anguilla) has both scales and fins and is, biologically speaking, a fish. Yet eels appear notably different from most fish, with fins and scales submerged beneath a thick, mucous-coated skin (hence the enduring Mosaic prohibition). Perhaps most significantly this gives the eels the appearance, if not the texture, of a serpent. In a crude version of Douglas' thought, this taxonomic ambiguity might itself precipitates an aversion to eels. It could also be that, given that many human cultures display a tendency to take their own behaviors as a normative standard, both eels' and the serpents' uncanny form of locomotion, which is unlike most other creatures, would also be experienced as disturbing.

However, that eels might be so readily confused with snakes leads us back to the account of disgust as 'hard-wired.' Studies of the distribution of phobias in Europe and America have tended to reveal clusters around particular animals, snakes in particular. Accordingly, phobias of snakes have long been roped into assertions that the foci of our disgust and fear are phylogenetically determined (Angyal 1941). Yet confronted by such studies, one might be lead to ask why, if it would serve an evolutionary purpose, we are not also spooked by mosquitos or disgusted by bears, and why also it is that psychiatrists also find themselves dealing with fears of dentists, needles and flying, along with disgust at objects like buttons. Moreover transnational studies of 'universal' human phobias (Prokop et al. 2009, Davey et al. 1998) alongside experiments with unflinching hand-reared primates (Joslin and Fletcher 1964, Hinde 1991) suggest that human aversions to snakes are not quite as 'innate' as some have suggested, and that culture and experience might play an important role in even these apparently primal fears.

To be sure, it would be logical for humans to have evolved a propensity towards ophidiophobia. However there are a remarkable number of culturally defined categories that the eel slides in 
between and outside of, and which offer a number of other possible explanations for the general unease expressed in the presence of Anguilla anguilla. For instance, like some snakes, the European Eel survives both in water, and for a time, on land; making slow wriggles across miles of hard earth when migratory urges require it. Moreover, unlike many fish, they are at home in both ocean brine and muddy freshwater inland. Accordingly, in view of what Reitz and Wing $(1999,33)$ refer to as "folk taxonomies" the eel is an epistemologically slippery character; a character trait that, through a Douglasian lens, offers a compelling explanation for at least a portion of the squirms with which they are consistently met.

If we are considering the classificatory systems upset by the jellied eel then we must also, of course, consider the jelly in which the eel comes nestled. Amongst those expressing an aversion to the eels, the jelly was often identified as being the ultimate repellant. Even amongst the handful of visitors to the stand that I eventually cajoled into joining me with a bowl of eels, it was not uncommon for the participant to exclaim "I might be able to eat the eel, but without the jelly." If we take Douglas' account of disgust literally, jelly might be understood as disturbing for its ability to exist in an ambiguous state between a solid and a liquid. Given its brittle gooeyness, jelly does not easily fit into the categories through which we generally encounter physical substances. However, it is not necessarily the ambiguity of jelly itself that is its most disturbing characteristic. What seem to be the most disturbing fact about jelly, as well as its cousins, slime and gunk, is that they can easily adhere to the skin of those that come into contact with them. As Sartre details in his meditations on slime $(1969,608-$ 610), and as Kristeva notes in her diatribe against the skin that forms on warm milk (1982, 2-3), adhesiveness can be amongst the most disturbing of sensory qualities, not least because a sticky texture, like a clingy smell or lingering taste, threatens the foundational division between self and world by smudging the sensed boundaries of the body. There are, suffice to say, a number of reason why jellied eels might find public relations a particularly difficult struggle. 
Yet, as mentioned briefly above, in the not too distant past, chunks of eel swimming in their own congealed juices were a central part of many Londoner's diets, with just short of ten million eels sold in the city during 1850 (Mayhew 1851: 63). These sales figures, combined with the numerous skeletons of old eel shops that spatter contemporary London, would suggest that at one time, significant part of the population displayed no aversion towards the fish, nor jelly in which they were regularly sold. Between now and then, it would seem, a number of intervening variables have emerged that have come to prefigure the squirms currently directed at this dish. However, looking at mere aversion to specific foodstuffs themselves might, if you will allow the pun, be a red herring. As my own ethnographic endeavours, and a number of sustained sociological studies of taste (Charles and Kerr 1988, Lawler 2005, Lupton 1996, Bourdieu 1984, Bennet et al. 2009) suggest, many of the decisive factors, lie beyond the epistemological liminality of eels and their piscine neighbours as objects in themselves. What determines a squirm in many instances, it seems, is not the flavour, smell or texture of food itself. Rather it is the broader cultural associations that spring forth from the encounter with the taste, smell and texture of a foodstuff, and the space in which it is consumed. For, when experiencing any food, we are often not simply responding to our understanding of a flavour, smell or texture, but also to the associations we attach to the combination of the flavour and the wider spatial and cultural milieu in which it is nestled. In short, smells, tastes and textures are laden with cultural associations and our responses to them are active in making and remaking cultural distinctions. For the jellied eels and the site of their encounter in particular, these meanings are entwined with the city's history of socio-economic segmentation.

\section{Classy Tastes}

Let us then, move away from a consideration of the way in which items on Tubby's menu are classified and towards a consideration of the ways in which the assemblage of the stand's patrons and the flavours and aromas of their environs are understood. In a 1960s survey of the differentiated lives of 1000 French people, Pierre Bourdieu (1984) famously identified clear distinctions within the habits 
of his study participants, in particular within their habituated gustatory 'likes' and 'dislikes'. Whilst these differences correlate with the gender and age of his participants, Bourdieu identifies the most powerful correlation being that between that between taste, and socio-economic class. Importantly, for Bourdieu, differences in taste or aesthetic preference are far from incidental to socio-economic processes. Rather, taste cements individuals into a socio-economic hierarchy, signalling an individual's similarity with others in her class, and providing a means by which to identify others' relation to her. Perhaps more importantly given our concerns, the regime of taste upholding the internal consistency of distinct social classes seems to be policed by an accompanying regime of distaste. This regime of distaste comprises culturally bequeathed gut feelings for the boundaries of ones own class. The taxonomy of meats, wines, cheeses and dining habits that mark the cultural boundaries between classes in Bourdieu's famous study are, of course, peculiar to the French history and its own species of western capitalism. Looking more closely at the British case, however, it seems highly plausible that the squirms directed at this particular genre of seafood are related to an analogous articulation of British class boundaries.

Certainly a taste for seafood and fish in London has, historically, had a great deal to do with social class. The history of a local taste for seafood in London is as long as history of London itself, which, since its establishment as a port city, has been open to the sea. While they were not the first inhabitants of the Thames Valley, it was Roman occupiers who first bought a taste for seafood to the city they named Londinium (Locker 2007), the fauna of the Thames and it's estuaries having been apparently shunned by pre-Roman inhabitants. Even at this early point, a taste for seafood might have been active in marking out a type of class distinctions, providing an important gustatory difference between the oyster-guzzling Mediterranean occupiers, and the locals who feared and revered both the Thames estuary and its contents. The role of piscine flesh in marking the boundaries between more explicitly socio-economic forms of distinction, however, begins later in the city's evolution. 
In Elizabethan London, as across northern Europe, seafood was the foundation of expanding empires, in an economic, calorific and technological sense. It has been argued that the protein hauled out off the British Isles' coasts were, to sixteenth century London, as important to the expanding economy as North Sea oil is today (Dyson, 1977: 43). As well as providing the amino acids and nutrients behind northern Europe's emerging industrial muscle, by way of the boat building industry fishing was also intertwined with the development of navies and a growing global trade in commodities and humanity. These developments also had an impact on the economic structure of society and the distribution of tastes and distaste across it. As boats dispersed out of the Thames and fur ther into the Atlantic and North Seas, there was also growth in a wealthy, non-aristocratic bourgeoisie. As Norbert Elias (2000: 42) famously detailed, with such upward mobility, there were incentives for the residual aristocratic elite to distinguish themselves from the new business classes. Simultaneously there was an incentive for the new business class to distinguish themselves form the labouring they had emerged from. One of the ways in which this drive to distinction was met was through the development of class specific sensoria and sensibilities through which to identify the sensoria that surround others. As Stephen Mennel has detailed, the production of cultural distinctions was particularly evident in the gustatory life of early modern Britain (1996: 127-133), and served to mark an individual's place in that society.

While the differences between class repertoires were partially symbolic, they also had an economic basis, with higher social class tastes correlated with higher exchange values, which was often, in turn, dictated by scarcity. Accordingly, as Europe trotted out of its sixteenth century - the rarer fresh, light white meats - were savoured for their contrast to the abundant dark, bloody wholegrain cuisine of peasants (Camporesi, 1998: 36; 1989: 35 and 164). However, scarcity is by no means a fixed attribute, and accordingly, neither is class loyalty to a particular flavour. Over the next two hundred years, as scarcity values of various fish and molluscs decreased, prompting changes to the regime of distaste upholding socio-sensory boundaries of social class. We can see these simultaneously economic 
and cultural shifts in the value in the biography of oysters which have, according to their availability, oscillated between a food of the powerful and a food of the poor several times over the last two millennia. We can also see it in the biography of most other items sold today at Tubby Isaac's. As economies grew, so too did the hulls of the fishing 'smacks' allowing space for ice, saltwater tanks and storage of larger nets (Dyson 1977: 66). This increased the masses access to fish living in the near shallows, and for the first time a taste for the shallow water creatures - herring, oysters, eels - became increasingly embedded within labouring lives. At the same time, and in an inversion of contemporary tastes (where fried cod is yoked to a working class British identity), exotic dishes such as 'whole cod's head ... with the fresh tang of the ocean deeps in its flesh was rare and prohibitively expensive', reserved for the wealthiest of dining tables (Dyson 1977: 67).

Even the price of cod would plummet when in the late nineteenth century, steam power precipitated the discovery of newly accessible deep water fishing grounds. However it was less the waterborne advances of the steam boat, than the land-borne advances of rail travel that had an impact on most on the relationship between maritime flavours and the everyday gustatory culture of Londoners. The weaving of steel threads across the country and the rolling of carriages across them, irreversibly yoked the flavours of the British coast to the working lives of the early modern metropole. Because of rail travel, masses of city dwellers from across London began departing for short trips to the wet sands and rock pools clustered around the cliffs and dunes of the south east shores. Lines such as the Great Eastern Railway's 'cockle special' to Southend, stopped at all stops in the east of London before depositing its passengers to stand with sand between their toes, up to their knees in coastal water. More significantly, on the way to such trips, which no doubt intensified a taste for the sea, colossal trains laden with molluscs and fish were passing in the opposite direction, towards London. So voluminous was the daily movement of sea-fauna across the country by rail that the main rail companies soon opened special departments to co-ordinate the unprecedented land-borne marine migrations (Gifford 1886: 2003). Not only did the modern age affect the quantity and range of fish 
available to Londoners but also the price, placing fresh seafood within daily life of a majority of working Londoners, and thereby associated with them. As nineteenth century commentator Henry Mayhew notes

\footnotetext{
'The rooms of the very neediest of our needy metropolitan population always smell of fish... So much so, indeed that those who, like myself, have been in the habit of visiting their dwellings, the smell of herrings, even in comfortable homes, savours from association, so strongly of squalor and wretchedness, as to be most often oppressive' (1851: 62).
}

Particularly interesting here is Mayhew's use of the word 'association.' It is not simply the raw materiality of the smell that elicits disgust. It is, rather, it's signification of 'wretchedness', a desperate quality that Mayhew finds distressing and emphatically disassociates from his own social milieu. In this way, as well as providing calories for the sustenance of an industrial workforce, fishy flavours and a distaste for them were also key components in the cultural machinery of industrialising London. A diet of oysters, herring, cockles and eel became a marker of class. At the same time, visceral offence at the sensory world of working class lives became a particularly potent way of shoring up an uppermiddle-class sense of distinction, and associated privilege.

Given the intertwined histories of seafood and social class, the disgust reserved for Tubby Isaac's eels and cockles might easily be understood as the endurance of a nineteenth century regime of class distaste. Without a doubt, a taste for these morsels is partially attributable to the mimetic transmission of class cultures across generations. One of Tubby Isaac's regular visitors, for instance, is a middle aged man who appears every now and again buys two of nearly everything: two medium portions of jellied eels, two pints of whelks, two pints of cockles and two roll mop herrings, all 'to takeaway.' One portion is for him, the other for his grandfather, an old dock worker, now in a care home on the outskirts of East London. If class tastes endure across centuries, then surely the same might be said for distaste. As Charles and Kerr's (1988: 192) survey of domestic regimes of taste 
makes plain, middle-class antipathy towards the sensory signifiers of working class lives was alive and well twenty years ago, and as recent studies have argued (Wills et al., 2011, Bennet et al., 2009), a regime of taste and distaste remains partially correlated with socio-economic class endures. However, as Juilan Brannen (2007) has argued, the history of twentieth century Britain has also had an impact on the type, and intensity, of intergenerational transmission. The associated shift towards post-industrial forms of production - the valorisation of service industries, the decline of manufacture, the increasing economic centrality of cultural consumption - have all variously interfered with the transmission of taste and distaste, as have the osmosis of novel flavours and textures through new transnational connections. In short, the consumption habits of the bulging middle-classes in both the UK and U.S. have been muddied by the evolution of 'cultural omnivorousness' (Peterson and Kern, 1996). Accordingly it is unsurprising that, in probable distinction to their grandparents, a plumber and his wife that visit Tubby Isaac's claim they are as likely to venture to Selfridges for sushi, or tour France sampling fine wine, as they are to patronise Petticoat Lane for a weekend bowl of jellied eels.

However, none of these rules out the possibility that squirms directed at the seafood stand are unrelated to socio-economic class. For a start, as Warde (2007), Savage and Gyao-Cal (2009) have argued, both the extent and novelty of omnivorousness are over exaggerated in contemporary sociological literature. There is also a way in which we might argue that the distaste for Tubby Isaac's might be directly attributable to the class turbulence of the last century. As Stephanie Lawler's research argues (2005) the growth of an apparently middle-class mass culture over the last fifty years, for all of its apparent mutability and omnivorousness, has required figures against which to cast itself. In short, for Lawler, the making of the middle-classes has had, at its core, distaste for standardised signifiers of working-class culture, in particular signifiers of their 'emblematic whiteness' (2005: 4030), which clashes with their own pretensions to cosmopolitanism. For some, it seems, an idealised folkish image of London's white, working class Eastenders - guzzlers of eels and pies - might 
provide a sort of domesticated folk devil through whom simultaneously moral and gustatory entrepreneurs can shore up a hegemonic middle-class culture.

\section{Generational Distinctions}

If that is the case that a new middle-class culture emerged out of the changing fortunes of the late century's industrial proletariat, then the the squirms that are produced when members of this new class encounter their parent's favoured jellied snacks are not merely directed at threats to the younger generation's precarious sense of class distinction. Entangled within those squirms, is also necessarily a sense of generational distinction. Consider the following exchange between a mother and daughter. The daughter, a civil servant in her early forties, currently residing in a wealthy northern London borough, had care of her mother, and erstwhile East Ender for the Christmas period and had taken her to Tubby Isaac's specifically, as many former locals do in the few days between Christmas and boxing day, to have the jellied eels she had grown up with. The elder of the two was doing most of the talking and eating.

'You'll never get jellied eels the same as 'ere. These are still the best.' The small elderly woman pauses between mouthfuls, steps back and places one hand on the steel counter before and shakily lifting the blue plastic fork to her lips. She manoeuvres another inch long segment of eel into her mouth and starts parting all the flesh from the bone expertly with her tongue, her paper thin cheeks revealing every movement inside her mouth. Discretely catching the bone from her mouth and swallowing, she continues. 'But Petticoat Lane is nothing like Petticoat Lane I knew. All the stalls... I got my fur coat here. It was a very Jewish area. There's none now. There used to be nice little cafes, real food, cauliflower cheese and things ... the chickens hanging up there and blood dripping in the barrels.' The daughter looks from her mother, to whom she was listening and towards me, and performs small silent vomiting motion, seemingly sincere, but followed by a smile suggesting that all of those present would share a distaste for the sensory world of her mothers recollections. The elder of the 
two went on to consume a large bowl of jellied eels and a small tub of the whelks. Her daughter turned down her mothers insistent offer of a small bowl of eels, ('I've never liked them mum!') before opting, like so many others perturbed by the piscine viscera, for a clutch of crab flavoured sticks. In this instance it seems plain that the social boundaries policed by visceral disgust are not simply the membranes of class culture. In this instance, the nose, tastebuds and stomach combined are also the newly appointed guardians of generational senses of difference, and a site of a disjuncture in the mimetic transmission of class culture. Together the sensations of the stand and its environs, are experienced through a sensibility that disrupts the intergenerational transmission of classed identity while shoring up a newly aspirational and cosmopolitan middle-class self.

\section{Really Dirty}

Few of the contorting guts represented here result from any immediate physical threat to the body. With genuinely poisonous vapours and violent social types sublimated by the modern city's infrastructure, squirms seem to predominantly arise from the contravention of categories imprinted on the senses by matrices of culture, language and knowledge. The space around Tubby Isaac's, the smell of piscine flesh, the texture of a jellied eel and the casual xenophobic banter shared between its patrons are only 'symbolically dirty' according to particular sets of arbitrary linguistic and cultural categories through which everyday experiences are made sense of. Accordingly the squirms directed at the stand could be considered as a response to threats to the consistency of the cultural know ledge, practices and language that live through the body of the squeamish. However, there are significant dangers in this reading. Following a caution offered by Carol Wolkowitz (2008, 15), we need to be acutely aware of first; the extent to which the 'cultural' focus obfuscates the all too real consequences of this arbitrary assignation of dirt. Second; we also need to be sensitive to the extent to which the social scientific definition of dirt might precipitate an insensitivity to the abundance of 'real dirt' within contemporary lives and the genuine threat it poses to human life. 
In this sense, the social scientific ignorance of 'real' dirt is very similar to the natural sciences' disregard of cultural dirt. Both emerge from a refusal to distinguish the objects of each other's study from one and other. One consequence of this mutual refusal to distinguish culturally constructed dirt from real dirt is the inability to challenge social situations in which both 'real' dirt and 'cultural' dirt are erroneously and unjustly allocated to the same social and geographic spaces. We see such tendencies, for example, in Indian cities wherein those designated as 'untouchable' at birth according to enduring cultural taxonomies, live amidst the worst of the pollution a rapidly expanding city can produce. We also see such tendencies across the history London, a city in which the same spaces that have historically been home to 'culturally' dirty figures, also harboured disproportionate threats to the mortality of their inhabitants. For example, because of the prevailing westerly winds, the entire area around Tubby Isaac's has historically languished in both west London's miasmic shadow, and the local odours of an area favoured for the location of slums, cemeteries, plague burial pits, tanneries, and sweatshops. In the same way that the seat of power has historically sought to keep genuine toxins down wind, the same the area was also allocated home to a remarkable constellation of radical political dissenters, exiles, artists, addicts, nonconformist Christians, Jews, anarchists, Chinese merchants and Bengali sailors; all perceived threats to the valorised culture of the city, yet also all tasked with operating its most dangerous machinery, or at least living amidst its exhaust.

Today much of the 'hardware' that sustained physical distinctions between east and west London has gone: The old docks and fish market have been relocated further east toward the mouth of the Thames. Manufacturing has been outsourced to industrial zones in the global south, and the effluent once carried by air and water from the west has been channelled into sewers and underground rivers. With the recent addition of Olympic developments - shopping malls, parks - and extensively refurbished heritage zones, the East End has become increasingly similar in appearance to the his torically cleaner and respectable west. Which is not to say that pockets of it are no longer home to real dirt, nor symbolically dirty social types. 


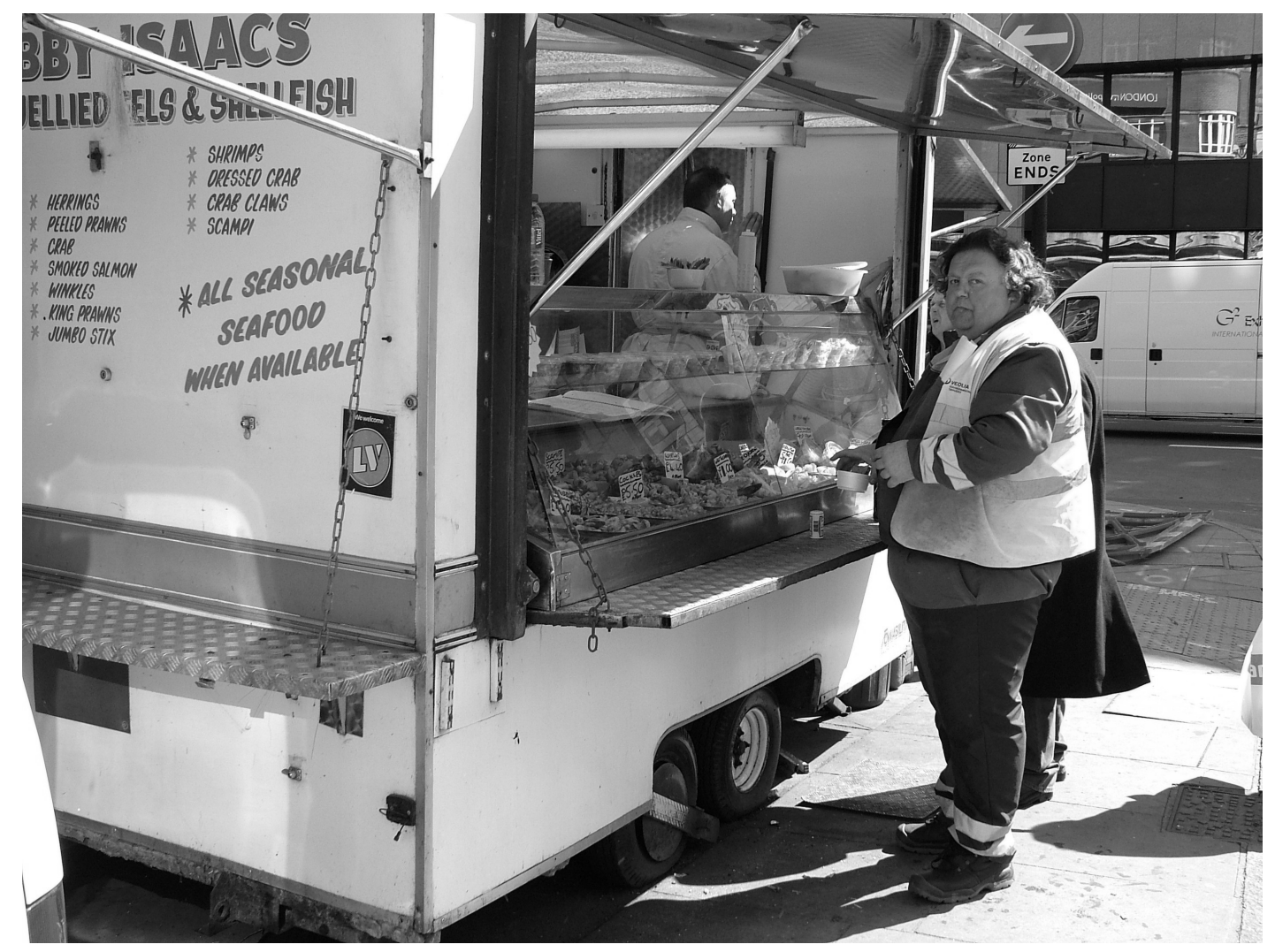

Figure 4. Tubby Isaac's, 2008, author's own photo

Consider this portrait of one Tubby Isaac's most regular types of customers, one of a team of local street cleaners, a warm, familiar and popular character in the neighbourhood (Figure 4). Many of his fellow 'refuse collector-cum-exterior designers,' (Sandu, 2007) visit the stand during or after their shift of scraping and sweeping. In the case of this mixed gaggle of Polish, Caribbean, British and West African labourers, hanging around symbolically 'dirty' space, eating symbolically 'dirty' food, telling symbolically 'dirty' stories, it's essential not to lose sight of the fact that the 'symbolic dirtiness' of their habitus, coincides with really dirty work; handling needles and broken glass through thin rubber gloves, wondering alone on streets mopping up the sludgy residues of the East Ends exploding nighttime economy. Posing far greater personal risk than the 'risks' handled by the financial wizards in the neighbouring city this is work - dished out to members of society often perceived to threaten normative forms of propriety - threatens the very real boundary between life and death. The arresting of the symbolically dirty to real dirt can also be seen in the life of the sex workers whose shifts overlap with those of the area's street cleaners. ${ }^{2}$ And of course, labouring both physic- 
ally and culturally, at the 'edge of British society', it serves to recall the migrant labourers, denigrated at the very start of this paper when the aforementioned cabby greeted the proprietor of the seafood stand with the question 'still killing them Chinese?'. Morecambe Bay's cockle pickers, migrants from China who, alongside symbolically dirty working-class northern Brits and eastern Europeans, were undertaking work that was so literally dirty, so potentially injurious, that at least 23 lives were lost to the dawn tides of February 2004. Identified through the sounds, smells and sights that surround them as symbolically dirty, all the above are also chained to real dirt. Certainly, the squirms that this essay has focused upon mark real dangers. However, this danger is far less pressing for those identifying the dirty smells, sights, sounds and flavours, than those whose lives are being reviled or joked about.

\section{Conclusion}

In most instances the curling upper lip or pouting lower lip elicited by the sea food sold at Tubby Isaac's, often has very little to do with any immediate threat or the identification of 'real' dirt. Rather, it marks the moment that the body reinforces the cultural sensibility through which they make sense of the world. Squirms, however, do a lot more work than the reinforcement of abstract linguistic categories and cultural taxonomies. Expressions of distaste and disgust are active in the making - and remaking - of social categories that have a very real impact on everyday life of the city and its inhabitants.

Through the squirms directed at the seafood stand it is possible to witness class and ethnicised forms of distinction being unwittingly remade, but also transformed as the changing economic and cultural background of the city inflect the sensibilities of new generations. Of course, the seafood stand, and people's various experiences of it are relatively insignificant within the wider landscape of the city. What these ethnographic episodes tell us, however, about the low level gut feelings that flash across the backdrop of everyday urban experience is important. Alongside the myriad of analogous feelings and sensations that accumulate in bodies everyday, such reactions constitute significant 
forces of both social reproduction and change. While drawing on the bodies' capacity for self defense, squirms are often shaped and set off by cultural contours of everyday life and, as such, are often far more arbitrary than often assumed or felt. While we might not want to ignore them altogether - for fear we might miss some real danger - thinking twice about the gut feelings that guide people through their everyday lives is an important practice in the move towards more just societies in which cultural taxonomies and judgements of taste do not play such decisive and fatal roles.

Andrews, J., (2003), 'Sands of Change, Portrait of the Cockle fishery in Morecambe Bay November 2002-October 2003' Shellfish News Centre for Environment, Fisheries \& Aquaculture Science (16): 21-24.

Angyal, A., (1941). Disgust and Related Aversions. The Journal of Abnormal and Social Psychology, 36(3), pp.393-412.

Back, L., \& Lyon, D. (2012). Fishmongers in a Global Economy: Craft and Social Relations on a London Market. Sociological Research Online, 17(2), p.23.

Barker, T.C., Mackenzie, J.C. \& Yudkin, J., (1966), Our changing fare: two hundred years of British food habits; edited by T. C. Barker, 7. C. McKenzie and John Tudkin, London: MacGibbon \& Kee.

Bell, D. and Valentine, G., (1997), Consuming Geographies: We Are Where We Eat, London, New York: Routledge).

Bennett, T., et al.. (2009), Culture, Class, Distinction, London: Taylor \& Francis.

Berendt, J.-E., 1992. The Third Ear: On Listening to the World, Henry Holt \& Co.

Bourdieu, P., (1984), Distinction: A Social Critique of the Judgement of Taste, Cambridge MA: Harvard University Press.

Brannen, J., (2006), Cultures of Intergenerational Transmission in Four-Generation Families. The Sociological Review, 54(1), pp.133-154.

Callon, M., (1986), Some Elements of a Sociology of Translation: Domestication of the Scallops and the Fishermen in John Law Power, Action and Belief: A New Sociology of Knowledge? London, Routledge \& Kegan. Camporesi, P., (1989), Bread of Dreams - Food and Fantasy in Early Modern Europe, Chicago: University of Chicago Press.

Camporesi, P., (1998), Exotic Brew - The Art of Living in the Age of Enlightenment, London: Polity.

Charles, N. and Kerr, M., (1988),Women, Food, and Families, Manchester: Manchester University Press.

Cohen, P., (1998), The Last Island, Dagenham: Centre for New Ethnicities Research. 
Crompton, R., (2006), Class and Family. The Sociological Review, 54(4), pp.658-677.

Davidson, K. and Bresnan, E., (2008), 'Harmful Phytoplankton, Shellfish Poisoning and Human Health,' Shellfish News, Centre for Environment, Fisheries \& Aquaculture Science (26), $18-20$

Davey, G.C.L. et al., (1998), A cross-cultural study of animal fears. Behaviour Research and Therapy, 36(7-8), pp.735-750.

Douglas, M., (2002), Purity and Danger, London, New York: Routledge.

Dyson, J., (1977), Business in Great Waters: The Story of British Fishermen, London: Angus and Robertson Publishers.

Elias, N. et al., (2000), The Civilising Process, Hoboken: Wiley-Blackwell.

Gifford, W. et al., (1886), The Quarterly Review, Vol. XCV, London: J Murray.

Grosz, E., (1994), Volatile Bodies, Sydney: Allen \& Unwin.

Hinde, R.A., (1991). A Biologist Looks at Anthropology. Man, New Series, Volume 26, pp.583-608.

James, W., (1960), The Varieties of Religious Experience, London: Plain Label Books.

Joslin, J., Fletcher, H. \& Emlen, J., (1964). A comparison of the responses to snakes of laband wild-reared rhesus monkeys. Animal Behaviour, 12(2-3), pp.348-352.

Kristeva, K., (1982), Powers of Horror: An Essay on Abjection, New York: Columbia University Press.

Lawler, S., (2005), Disgusted Subjects: The Making of Middle-Class Identities. The Sociological Review, 53(3), pp.429-446

Locker, A. (2007), 'In pibiscus diversi; The Bone Evidence for Fish Consumption in Roman

Britain,' Britannia, XXXVIII.

Lupton, D., (1996). Food, the Body, and the Self, London: SAGE.

Mayhew, H., (1851), London Labour and the London Poor: A Cyclopaedia of Conditions and Earnings Vol. 1, London: Griffin Bone and Company.

Mennell, S., (1996), All Manners of Food, Chicago: University of Illinois Press.

Narayan, U., (1995). Eating cultures: Incorporation, identity and Indian food. Social Identities, 1(1), p.63.

Öhman, A. \& Mineka, S., (2001). Fears, phobias, and preparedness: toward an evolved module of fear and fear learning. Psychological review, 108(3), p.483.

Peterson, R.A. \& Kern, R.M., (1996). Changing Highbrow Taste: From Snob to Omnivore. American Sociological Review, pp.900-907. 
Prokop, P., Özel, M. \& Uşak, M., (2009). Cross-Cultural Comparison of Student Attitudes toward Snakes. Society and Animals, 17(3), pp.224-240.

Reitz, E.J. Wing. E.S., (1999), Zooarchaeology, Cambridge: Cambridge University Press.

Sandhu, S., (2007), Night Haunts, London: Artangel.

Sartre, J.-P., (1969), Being and Nothingness: An Essay on Phenomenological Ontology, London, New York Routledge.

Savage, M. and Gayo-Cal, M., (2009)., Against the Omnivore: Assemblages of Contemporary

Musical Taste Working Papers, Manchester: University of Manchester, CRESC.

Toronchuk, J. A. Ellis, G. F. R., (2007), 'Disgust: Sensory Affect or Primary Emotional

System?', Cognition \& Emotion, 21:8,1799 - 1818.

Walton, J., 2000. Fish and Chips and the British Working Class, 1870-1940, London: Continuum

International Publishing Group.

Wolkowitz, C., (2008), 'Linguistic Leakiness or Really Dirty' in B. Campkin and R. Cox Dirt London: I.B. Tauris.

Warde, A., Wright, D. \& Gayo-Cal, M., (2007), Understanding Cultural Omnivorousness: Or, the Myth of the Cultural Omnivore, Cultural Sociology, 1(2), pp.143 -164.

Wills, W. et al., (2011), The Framing of Social Class Distinctions Through Family Food and Eating Practices. The Sociological Review, 59(4), pp.725-740. 
1 In February, 2004, Yu Hui, Chen Muyu, Guo Nianzhu, Lin Zhifang, Xu Yuhua, Wu Jianzhen, Wu Hongkang, Xie Xiaowen, Lin Guohua, Guo Binglong, Zhou Xunchao, Lin Guoguang, Gao Chaokun, Guo Changmau, Yang Tianlong, Lin Lishui, Wang Minglin, Lin Youxing, Chen Aiqin, Zhang Xiuhu and Wang Xiuyu were killed picking cockles in the tides of Morcambe Bay, Lancashire. The notorious tides were however, only the executors, their fate being determined initially by the closure of several cockle fisheries around the coast in 2003, a response to bacterial control measures. Details of the deaths and the charges are widely available through the mainstream press. For a very interesting account of the shift in fishing practices at Morecambe bay that occurred two years before these deaths see Jeffery Andrews (2003) account in 'Shellfish news'.

2 Bonnie Garrett, a local sex worker was one of two women, the other a local pirated DVD vendor called Xiao Mei Guo, recently abducted all but 100 meters from Tubby Isaac's. Both were raped and murdered by a man that the ruling QC remarked, 'preyed on the edges of society' - a geographically and socially accurate summation. 